\title{
La reforma constitucional de 1949: influencias y apoyos intelectuales a la iniciativa peronista
}

\section{The constitutional reform of 1949: influences and intellectual support for the peronist initiative}

\author{
Gonzalo Rubio García \\ Facultad de Filosofía y Letras, \\ Universidad de Buenos Aires, Argentina \\ Gonza_rubio@hotmail.com
}

\begin{abstract}
Resumen
A lo largo del siglo XX, varias naciones reformaron sus escritos constitucionales decimonónicos con el propósito de ampliar los derechos de los ciudadanos e incorporar regulaciones económico-sociales. La reforma de la Constitución se instauró en la Argentina hacia el año 1949 en un contexto de gran polarización política. En este artículo buscaremos exponer los diferentes argumentos que mostraron los intelectuales y políticos peronistas para defender la iniciativa reformista, teniendo en cuenta, además, las diferentes cosmovisiones que esbozaron y las influencias de otros intelectuales que recibieron los senadores y diputados.
\end{abstract}

Palabras Clave

Nacionalismo, peronismo, historia del derecho, historia intelectual, revisionismo histórico.

\begin{abstract}
Throughout the twentieth century, several nations reformed their nineteenth-century Constitutions in order to broaden the rights of citizens and incorporate socio-economic regulations. The reform of the Constitution came to Argentina in 1949 in a context of great political polarization. In this article we will try to explain the different arguments that peronist intellectuals and politicians provided in order to defend the reformist initiative, taking into account also the different worldviews they outlined and the influences of other intellectuals received by senators and deputies.
\end{abstract}

Keywords

Nationalism, Peronism, Law History, Intellectual History, Historical Revisionism. 


\section{La reforma constitucional de 1949: influencias y apoyos intelectuales a la iniciativa peronista}

\section{Introducción}

La reforma de la Constitución en 1949 incentivó debates y posiciones encontradas en la primera presidencia peronista. A lo largo de la historia se presentaron gran cantidad de obras que mostraban proyectos alternativos al de 1853, ${ }^{1}$ pero hacia el final de la década de 1940 fue que el contexto político de época posibilitó la modificación constitucional.

En los primeros cuarenta años del siglo XX, muchos países reformaron los textos decimonónicos con el propósito de fortalecer a sus estados, ampliar la representación política de los ciudadanos e incorporar regulaciones económicas y sociales. En todos los casos se daba importancia a los intereses sectoriales en desmedro de los partidos políticos, aunque cada Nación tuvo sus singularidades al momento de establecer los cambios constitucionales.

Los intentos de reforma argentinos buscaban quitar el tinte liberal que guardaba el texto fundador de mediados del siglo XIX y aproximarse al constitucionalismo social y corporativista cuyos antecedentes se encontraba en la República de Weimar de la Alemania de entreguerras y la España republicana. Se proyectaba establecer la propiedad nacional del subsuelo y la elección directa de senadores, del vicepresidente y el presidente, suprimiendo además la prohibición de reelección presidencial inmediata, entre otras cuestiones. ${ }^{2}$

Distintos intelectuales y políticos argentinos realizaron una defensa de la iniciativa peronista bajo argumentos que explicaban y justificaban la necesidad de una reforma constitucional. Muchos otros, a su vez, sin ser militantes peronistas, sirvieron de inspiración a dicho partido sobre los conceptos y derechos que debían incorporarse. En este trabajo aspiramos a analizar las posiciones respecto a la reforma de 1949, teniendo en cuenta, entre otras publicaciones, aquellas obras ${ }^{3}$ que sirvieron de antecedente a la Constitución y considerando los argumentos que aquellos intelectuales, políticos y convencionales expresaron respecto a la iniciativa reformista. También será necesario analizar los números 53 y 54 de la revista Hechos e ideas, ${ }^{4}$ publicación asociada al pensamiento peronista que editó los discursos pronunciados en la Cámara de Diputados de la Nación los días 13 y 14 de agosto de 1948. Examinaremos sus palabras en relación a la reforma, pues nos interesa demarcar cuales eran las ideas que circulaban

\footnotetext{
1Ver: "Apéndice". Hechos e Ideas, № 53, Año IX. Buenos Aires, 1948, pp. 269-272, Juan Fernando Segovia. "El modelo corporativista de estado en la Argentina, 1930-1945: Entre el derecho, la política y la ideología". Revista de Historia del Derecho, № 34. Buenos Aires, 2006, pp. 309-314 y Carlos Miguel Herrera. "En los orígenes del constitucionalismo social argentino: Discursos en torno a la Constitución de 1949". Historia Constitucional, № 15. 2014, pp. 392-395.

${ }^{2}$ Tulio Halperín Donghi. Argentina en el Callejón. Buenos Aires, Ariel, 2006, p. 133.

${ }^{3}$ En especial tendremos en cuenta los escritos de Alejandro Bunge y Carlos Ibarguren, pues fueron intelectuales que tuvieron mucha importancia en el campo de la economía política en la primera mitad del siglo XX.

"4Entre los años 1935 y 1941, la revista Hechos e Ideas estuvo políticamente ligada a la Unión Cívica Radical, siendo nuevamente publicada a partir de 1947 con un claro apoyo a la gestión peronista. Ver: Alejandro Cattaruzza. "Una empresa cultural del primer peronismo: la Revista $<<$ Hechos $e$ Ideas >> (1947-1955)". Revista Complutense de Historia de América, № 19. Madrid, 1993, pp. 270 y 277.
} 


\section{Gonzalo Rubio García}

dentro del peronismo, en la esfera pública, respecto a la Constitución, independientemente de la función que cumplieran en el partido.

Los autores considerados para este trabajo eran hombres de ideas que interpelaba a la opinión pública, mediante discursos y ensayos, con una misión cultural que estaba recortada por la configuración histórica de su tiempo. ${ }^{5}$ Desde un punto de vista normativo, se presentaban como escritores, políticos o intelectuales comprometidos con las luchas de su tiempo, buscando modificar o sostener distintas concepciones en la sociedad que, generalmente, estaban asociadas a un proyecto más amplio. ${ }^{6}$

Si bien los políticos e intelectuales circulaban, a veces, en ambientes diferentes, compartían un corpus de ideas, con sus matices, que es necesario analizar para lograr comprender las representaciones que formaban parte de la cosmovisión peronista. Para dicho análisis debemos tener en cuenta que el rótulo de intelectual no es una clasificación socio-profesional, "no remite a una ocupación determinada en algún sector del saber, sino al comportamiento de tales personas en relación con la esfera pública", el cual puede ser asumido de forma continua o intermitente. ${ }^{7}$

La mayoría de los autores tomados en cuenta para este trabajo, incluso aquellos que estaban ligados al mundo cultural e intelectual como Manuel Gálvez, Ernesto Palacio y Atilio García Mellid, circulaban entre ambos mundo, el políticopartidario y el intelectual, uniéndolos según las circunstancias. Por dicha razón, no debemos dejar de reflexionar sobre el peso intelectual que las figuras anteriormente mencionadas, a las cuales sumamos a Raúl Scalabrini Ortiz, tuvieron para distintos políticos peronistas. ${ }^{8}$ Además, trataremos, según cada caso y a lo largo del escrito, de establecer las funciones sociales que cumplían las figuras consideradas mediante una breve descripción de su accionar en la esfera pública.

Continuando la anterior lógica, circunscribimos el tipo de investigación que pretendemos desarrollar dentro del campo de estudios de la "historia de las ideas". La referencia a este término como "campo" no es casual, ya que sin bien se "inscribe su labor dentro de la historiografía (...) a veces, cruza el límite y se mezcla con otras disciplinas". ${ }^{9}$ Entendemos que los aspectos culturales ${ }^{10}$ deben analizarse bajo dicha tendencia historiográfica ya que busca "comprender las ideas y creencias del

\footnotetext{
5Para este tema, ver: Reinhart Koselleck. Historias de conceptos. Estudios sobre semántica y pragmática del lenguaje político y social. Madrid, Trotta, 2012.

${ }^{6}$ Carlos Altamirano. Intelectuales: Notas de investigación sobre una tribu inquieta. Buenos Aires, Siglo XXI, 2013, pp. 17, 55, 73 y 113-115.

7 Ídem, p. 111.

${ }^{8}$ En un encuentro con Juan Domingo Perón, aseguró Norberto Galasso, Scalabrini pidió que nacionalizara los ferrocarriles. Al parecer, el líder justicialista conocía sus obras y habían formado su pensamiento político. Ver: Norberto Galasso. Vida de Scalabrini Ortiz. Buenos Aires, Colihue, 2008, pp. 320-321.

${ }^{9}$ Carlos Altamirano. Para un programa de historia intelectual y otros ensayos. Buenos Aires, Siglo XXI, 2005, p. 10.

${ }^{10}$ Coincidimos con George Mosse en definir a la cultura, más allá de la vaguedad incorregible que conlleva el término, como un "estado o hábito mental que puede convertirse en una forma de vida íntimamente vinculada a los retos o dilemas de la sociedad contemporánea". Ver: George Mosse. La cultura europea del siglo XIX. Madrid, Ariel, pp. 12-13.
} 


\section{La reforma constitucional de 1949: influencias y apoyos intelectuales a la iniciativa peronista}

pasado" -los conceptos, palabras y representaciones sociales- utilizando escritos que restituyan la visión que los seres humanos tenían de su época. ${ }^{11}$ Sin embargo, debemos evitar caer en anacronismos al momento de leer las fuentes históricas, pues hay conceptos naturalizados en nuestra vida cotidiana -nación, patria, y muchos otros que podrían funcionar como ejemplos- cuyo significado era distinto en el pasado. ${ }^{12}$

Como anteriores estudios han demostrado y comprobaremos a continuación, consideramos que todos los intelectuales analizados basaban sus argumentos para reformar la Constitución en la crítica anti imperialista a la cultura extranjera y al paradigma liberal bajo el cual se había elaborado el escrito de 1853, así como también defendían posiciones relacionadas a la redistribución social, en especial al momento de analizar la propiedad privada. ${ }^{13}$

En relación a la anterior hipótesis, afirmamos que los diputados expresaron en sus discursos pensamientos relacionados a las posturas espiritualistas y anti materialistas que habían cobrado vigor en las primeras décadas del siglo XX, ideas que también eran parte de la cosmovisión que mostraron distintos intelectuales nacionalistas como Palacio, Gálvez y Scalabrini en torno a dicha época.

También sugerimos que las distintas posiciones que los intelectuales utilizaron para defender la reforma eran muestra de las posturas ideológicas que atravesaban al peronismo -sobre todo si nos atenemos al caso de Scalabrini y Palacio-, relacionadas, principalmente, a la idea de nación cultural que sostenían para la Argentina.

A su vez, consideramos que los diputados provinciales aprovecharon las sesiones del Congreso para reclamar por los derechos federales que les correspondían a sus provincias, mostrando los problemas que en la práctica ha suscitado históricamente dicha doctrina política.

\footnotetext{
${ }^{11}$ Oscar Terán. Historia de las ideas en la Argentina: Diez lecciones iniciales, 1810-1980. Buenos Aires, Siglo Veintiuno, 2012, p. 11.

${ }^{12}$ José Carlos Chiaramonte. Usos políticos de la historia: Lenguaje de clases y revisionismo histórico. Buenos Aires, Sudamericana, 2013, p. 277.

13 Varios estudios han analizado los ejes de la reforma constitucional bajo dicha óptica. Ver, entre otros: Alberto González Arzac. Sampay y la Constitución del futuro, Buenos Aires. Peña Lillo, 1982, Alberto González Arzac. La Constitución justicialista de 1949. Buenos Aires, El Alba, 1973, Carlos Miguel Herrera. "En los orígenes del...", Op. Cit., Ezequiel Abásolo. “El primer peronismo y la enseñanza jurídica universitaria. Protagonistas, actitudes y reocupaciones”. Cuadernos del Instituto Antonio de Nebrija de Estudios sobre la Universidad, №1, Vol. 11. Madrid, 2008, Jorge Reinaldo Vanossi. La Constitución nacional de 1949. Comunicación del académico Dr. Jorge Reinaldo Vanossi en sesión privada de la Academia Nacional de Ciencias Morales y Políticas, el 9 de noviembre de 2005. Buenos Aires, 2005, URL: https://www.ancmyp.org.ar/user/FILES/La constitucion.pdf y Santiago Régolo. Hacia una democracia de masas. Aproximaciones histórico-sociológicas a la reforma constitucional de 1949. Buenos Aires, Instituto Nacional de Investigaciones Históricas Eva Perón, 2013.
} 


\section{Antecedes e influencias sobre la reforma constitucional}

Las sesiones preparatorias para reformar la constitución se iniciaron el 24 de enero de 1949, siendo sancionado el nuevo escrito el 11 de marzo y jurado el 16 de ese mes. ${ }^{14}$ Sin embargo, la iniciativa reformista había tenido antecedentes en el gobierno peronista. Ya en septiembre de 1947 el Congreso había sancionado la ley que consagraba el voto femenino y con anterioridad, en febrero de ese año, se había buscado incorporar la nueva "declaración de derechos del trabajador" proclamada por Juan Domingo Perón, decisión que generó polémicas dentro de la oposición. ${ }^{15}$

A nivel regional se había generado un contexto de época favorable para elaborar iniciativas que tomasen en cuenta los reclamos obreros al momento de reformar los escritos constitucionales. Fue en América Latina donde se produjo la expresión del nuevo ideal mediante la célebre Constitución mexicana de 1917. Pero el más fuerte impulso se dio en los años treinta cuando países como Brasil, Uruguay y Colombia adoptaron distintas normas constitucionales en materia social. De esta forma, el escrito sancionado en 1949 tuvo antecedentes y llegó a la Argentina más bien en un período tardío en comparación a otras naciones. ${ }^{16}$

Fueron varias las figuras que aportaron sus ideas, incluso su imagen política, para teorizar la reforma. En general, había sido apoyada por la gran mayoría de los nacionalistas que buscaban oponerse a las ideas expresadas en el escrito liberal de 1853. Uno de los intelectuales que tuvo gran incidencia en las concepciones que luego transmitiría la reforma fue Alejandro E. Bunge (1880-1943). Su obra Una nueva argentina (1940) había tenido gran importancia en el pensamiento de Perón.

Bunge, hermano de las trascendentales figuras intelectuales Octavio Bunge y Delfina Bunge, se había dedicado a pensar la Argentina desde una perspectiva económicosocial. El autor destacaba los problemas sociales básicos argentinos: la natalidad, la vivienda obrera digna, el hogar rural en propiedad, la mejora de los niveles de vida y el aumento de la participación gremial y corporativa en la vida pública. En especial, insistía en la necesidad de "evolucionar" y aumentar la "representación de los intereses gremiales", pues, afirmaba, sólo así se salvaría la democracia. ${ }^{17}$

Las políticas sociales llevadas a cabo hasta 1940, destacaba, habían generado la decadencia demográfica: el predominio numérico de los "débiles corporales y mentales" era para el autor una realidad concreta. ${ }^{18}$ Para revertir dicha situación, Bunge proponía

\footnotetext{
${ }^{14}$ Las sesiones del Congreso se llevaron adelante sin los grupos opositores, pues el Partido Socialista se abstuvo de participar en la reforma, mientras que el radicalismo retiró sus 49 convencionales una vez iniciadas las deliberaciones en la Convención Constituyente. Así, formaron parte de la discusión general para luego retirarse en la discusión particular, pues solo asistieron a la primera sesión ordinaria del 8 de marzo.

${ }^{15}$ Carlos Miguel Herrera. “En los orígenes del...”, Op. Cit., p. 393.

${ }_{16}$ Pablo A. Ramella, senador nacional al momento de la reforma, era consciente del atraso constitucional argentino hacia 1949. Afirmó: "en el proceso institucional mundial puede decirse que no hay país que no haya introducido modificaciones o reformado totalmente su Constitución". Ver: Pablo A. Ramella. "Toda Constitución es producto de un proceso histórico y revolucionario". Hechos e Ideas, № 53, Año IX. Buenos Aires, 1948, p. 179.

${ }^{17}$ Alejandro Bunge. Una nueva Argentina. Buenos Aires, Hyspamérica, 1984, p. 19.

18Ídem, p. 26.
} 


\section{La reforma constitucional de 1949: influencias y apoyos intelectuales a la iniciativa peronista}

incentivar los natalicios, sobre todo los de las clases "más afortunadas". ${ }^{19} \mathrm{Al}$ mismo tiempo, destacaba la necesidad conseguir la independencia económica. Si bien aclaró que las relaciones con Gran Bretaña habían sido de utilidad recíproca, las circunstancias se habían modificado. Dicha nación, al igual que Francia, se caracterizaban por su autarquía, cuestión que nos dejaba "casi afuera de su órbita comercial". ${ }^{20}$ Así, la Argentina, "por su bien y por el de Europa", no debía seguir siendo un país exclusivamente "exportador de carnes, lanas cueros y cereales", sino que tenía que producir y exportar "petróleo, calzado, algodón y otras fibras textiles. ${ }^{21}$

En las ideas de Bunge, el Estado debía ejercer una amplia función de fomento y dirección general de la economía y la sociedad. ${ }^{22}$ En este sentido, era necesario, aseguraba, crear un régimen especial de la tierra que transformara paulatinamente al "agricultor nómade en el agricultor con arraigo", lógica que asociaba al concepto social de la agricultura. ${ }^{23}$

De todas formas, los antecedentes de la reforma encontraron un fuerte sustento en los escritos de Carlos Ibarguren (1878-1956),24 un intelectual-político que había ocupado varios cargos gubernamentales, mostrado un constitucionalismo abocado a lo social desde principios del siglo XX. Ya para 1934, año en que apareció su obra La inquietud de esta hora, había adherido al fascismo y lo expresaba mediante sus deseos de cambiar el texto de $1853 .{ }^{25}$ En dicho escrito, Ibarguren mostraba al fascismo, al corporativismo y la democracia funcional como repuestas superadoras de la sociedad y los movimientos políticos precedentes. Afirmó: "muchos creen que la crisis que hoy aflige al mundo es pasajera y que se retornará al carril optimista del liberalismo democrático y de la prosperidad indefinida (...) el capitalismo, tal como existió hasta ayer y la democracia individualista basada en el sufragio universal, fenecen". 26

El corporativismo mencionado por Ibarguren -doctrina política que sirvió en parte, no en su totalidad, de inspiración para la Constitución de 1949- era presentado como una tercera vía entre el capitalismo y el socialismo que hacía hincapié en los componentes económico-sociales. Dicha doctrina consideraba a la comunidad como un cuerpo orgánico que se articulaba mediante la solidaridad social y la distinción funcional.

\footnotetext{
${ }^{19}$ Ídem, p. 28.

${ }^{20}$ Ídem, p. 249.

21 Ídem, p. 251.

22 Ídem, p. 260.

23Ídem, p. 350.

${ }^{24}$ Tuvo una importante participación en política desde el 15 de octubre de 1930 -fue designado interventor de la provincia de Córdoba por José F. Uriburu, su primo-, al mostrar las bases que debía seguir la Revolución de septiembre para reformar la Constitución.

${ }^{25}$ Carlos Miguel Herrera. “En los orígenes del...”, Op. Cit., p. 397 y Fernando Devoto y Nora Pagano. Historia de la historiografía argentina. Buenos Aires, Sudamericana, 2009, pp. 215.

${ }^{26}$ Esta era la crítica que también hacía el revisionismo histórico a los sistemas políticos en torno a la década de 1930. Sus representantes se mostraban contrarios al rumbo elegido para la Argentina luego de la Batalla de Caseros (1952). Ver: Carlos Ibarguren. La inquietud de esta hora: Liberalismo, corporativismo, nacionalismo. Buenos Aires, Boldán, 1934, p. 5, Devoto y Pagano, Historia de la... Op. Cit., p. 218.
} 
Rechazaba el modelo político-representativo individualista y proponía la participación a través de grupos sociales. ${ }^{27}$

A los ojos de Ibarguren, en Europa se acercaba de forma amenazante la "fermentación social estimulada por el profundo malestar" que acechaba a la política y la economía. Así, en desmedro del liberalismo y el materialismo, representados por el "intelectualismo que dominó a fines del siglo XIX",28 ganaba lugar el fascismo corporativista, también por él denominado "nacionalismo", y el marxismo comunista. ${ }^{29}$ Estaban desapareciendo, afirmaba Ibarguren, los ideales de la Revolución francesa. La libertad se desvanecía tras la disciplina "mantenedora del grupo", mientras que la igualdad del "mito liberal" y la fraternidad eran remplazadas, no por el privilegio, "sino por la jerarquía indispensable a la organización colectiva” y "el arrebato combativo de la generación hija de la guerra". ${ }^{30}$

En su crítica a la sociedad liberal, Ibarguren destacaba la ineficacia que había surgido al dejar al libre albedrío la representación de los intereses sectoriales. Por esta razón, proponía que estuvieran representados en el Estado por sus genuinos representantes evitando así los elementos parasitarios del "profesionalismo electoral"."31 El Estado debía ser considerado como una síntesis de la Nación en donde predominaran los intereses del todo sobre los órdenes particulares y privados, pues el Estado liberal solo había degenerado en "demagogia u oligarquía". ${ }^{2}$ En su obra de 1934, incluso criticó la Constitución de 1853. Consideraba que el escrito había sido un paso institucional importante, pero que no había dado unidad a la Nación, especialmente por la tendencia centralista de Buenos Aires y el carácter "materialista" y "cosmopolita" del texto, ajeno a la "tradición heroica de la generación de 1810".33

Ya en la década de 1940, en vísperas de la reforma peronista, Ibarguren publicó una obra con su propuesta constitucional. Afirmaba que la "verdadera democracia" era la social y que debía estar estructurada mediante organizaciones orgánicas complejas, jerarquizadas y funcionalmente diferenciadas que representasen al "pueblo" a través de asociaciones económico-políticas y diferentes entidades culturales. ${ }^{34}$ Por "nuestra

\footnotetext{
${ }^{27} J u a n$ Fernando Segovia. “El modelo corporativista...”, Op. Cit., pp. 274-275.

${ }^{28}$ Carlos Ibarguren. La inquietud..., Op. Cit., p. 31.

${ }^{29}$ La crítica al "materialismo" era común en los grupos nacionalistas de principios del siglo XX que relacionaban dicha postura con la doctrina liberal. Sostenían que la implantación de ideologías europeas había corrompido los añejos ideales católicos e hispánicos que habían estructurado la sociedad argentina, logrando la defección cultural de la población. Manuel Gálvez, en particular, describía un presente degradado y reclamaba atemperar con retoques de "espiritualidad la barbarie de las energías materiales", producto del triunfo económico y social del inmigrante, quien había cambiado el concepto espiritual del país por un estilo de vida europeo. Ver: Manuel Gálvez. El Solar de la Raza. Madrid, Saturnino Calleja SA, MCMXX, pp. 13-14, 41.91 y 98, Manuel Gálvez. El diario de Gabriel Quiroga. Opiniones sobre la vida argentina. Buenos Aires, Taurus, 2001, pp. 75-76, 86, 90-91, Oscar Terán. Historia de las..., Op. Cit., p. 159 y Raúl Scalabrini Ortiz. El hombre que está solo y espera. Buenos Aires, Albatros, 1951, pp. 29-31, 35-39, 68 y 70, Carlos Ibarguren. La inquietud..., Op. Cit., pp. 7-8.

30Ídem, p. 35.

31Ídem, pp. 111-113 y 115-117.

32 Ídem, pp. 57 y $142-143$.

33Ídem, pp.149-151.

${ }^{34}$ Carlos Ibarguren. La reforma constitucional. Buenos Aires, Valerio Abelede, 1948, pp. 31-32.
} 


\section{La reforma constitucional de 1949: influencias y apoyos intelectuales a la iniciativa peronista}

idiosincrasia", creía en la necesidad de mantener al sistema republicano e incentivar un régimen presidencial fuerte. ${ }^{35}$

Su crítica partía de las consideraciones que los "liberales" habían tenido con el trabajador: para ellos, afirmaba, el trabajo era tan solo una mercancía más y no un derecho que dignificaba al hombre. Seguían las ideas de la Revolución francesa buscando exaltar la "libertad personal frente a la sociedad" y destruyendo las "asociaciones profesionales y gremios". ${ }^{36}$ El Estado, sostenía, debía intervenir -gozando de una vigorosa estructura que interprete las modalidades culturales y morales argentinas- en materia social para amparar al trabajador y sus familias. ${ }^{37}$

Las anteriores posturas, diseñadas en torno a la reconfiguración del Estado producto de la crisis surgida en la década de 1930, fueron reinterpretadas y retomadas en los años de la posguerra por el peronismo, aunque también formaban parte de las ideas que sostenía la UCR. Ya hacia el año 1936, Orestes Confalonieri, ex funcionario de la Dirección Nacional del Trabajo y director por un breve lapso de la revista Hechos e Ideas, cercano al forjismo, sostenía que, cuando la UCR recuperara el Gobierno, debía profundizar la “legislación social con una 'revolución' jurídica a través de la reforma de la Constitución para hacer reposar sobre basamento cierto el mejoramiento económico de las masas", dejando entrever la necesidad de crear un Ministerio de Bienestar Social e intervenir desde el Estado en materia de empleo. ${ }^{38}$

Es probable que las ideas para realizar una reforma constitucional llegaran, en cierta medida, del radicalismo al peronismo mediante aquellos militantes, con distintas ubicaciones en el espectro del partido, que se unieron al emergente movimiento peronista a mediados de la década de 1940 con el argumento de que la "peronización del radicalismo era consecuencia de la desradicalización del yrigoyenismo". Entre ellos se encontraba Hortensio Quijano y Diego Luis Molinari, aunque posteriormente se unieron otros radicales como Bernardino Horne y Pedro Oscar Murúa. ${ }^{39}$ También, debemos tomar en cuenta la migración de varios de los miembros de FORJA, ${ }^{40}$ como Arturo Jauretche y Homero Manzi, al peronismo, siendo aquella una agrupación radical en la que se había puesto en entre dicho las virtudes del escrito constitucional de 1853 en los términos que luego retomaría el peronismo. ${ }^{41}$

No debemos dejar de considerar, además, la influencia que ejercieron aquellos nacionalistas -como Palacio, intelectual-político que estuvo relacionado al grupo de pensadores que realizaron escritos en la década de 1930 para la revista La Nueva

\footnotetext{
35 Ídem, p. 15.

36Ídem, p. 20.

${ }^{37}$ Ídem, pp. 35-37.

38 Para este tema, ver: Ana Virginia Persello. Historia del radicalismo. Buenos Aires, Edhasa, 2007, p. 133.

39 Ídem, p 137.

40 FORJA fue un movimiento, surgido de la crisis de la UCR hacia mediados de la década de 1930, que intentaba recuperar las ideas de Hipólito Yrigoyen mediante una doctrina nacionalista y anti imperialista, siguiendo el hipanoamericanismo de Manuel Ugarte y Raúl Haya de la Torre.

41 Ver, entre otros: Luis Delepiane. "El petróleo de México y el deber argentino", en Ana Jaramillo, Cuadernos de FORJA. Remedios de Escalada, UNLA, 2012, pp. 206-207 y Raúl Scalabrini Ortiz. Política Británica en el Río de la Plata. Buenos Aires, Reconquista, 1940, p. 40.
} 


\section{Gonzalo Rubio García}

República y Nuevo Orden y ocupó los cargos de Ministro de Gobierno e Instrucción Pública de la Intervención Nacional en San Juan (1930-1931), presidente de la Comisión de Cultura (1946-1947) y diputado nacional (1946-1952)- que se habían arrimado a las ideas de Ibarguren y que terminaron formando parte del peronismo, llevando al partido un cúmulo de ideas cercanas al corporativismo.

Tomando en cuenta todas esas vertientes intelectuales de llegada hacia el peronismo, se explica que la idea de reformar el escrito decimonónico desde una óptica social rondara las diferentes corrientes de pensamiento en las décadas de 1930 y 1940. Había un clima de época en el que muchos intelectuales y políticos destacaban ciertos tópicos comunes que necesitaban ser plasmados en la Constitución: el anti imperialismo, la independencia económica, la intervención del Estado en el orden político-social, etc. Llegado el peronismo, las ideas de Bunge, Ibarguren, FORJA y otros intelectuales tomaron cause en el partido, sin que eso implicara el abandono de posturas similares por parte de la UCR y distintos movimientos políticos. Los simpatizantes peronistas resignificaron dichas posturas y presentaron al justicialismo como una doctrina revolucionaria que buscaba establecer una nueva concepción del mundo y de la vida, un relevo de los antiguos valores liberales que habían guiado a la sociedad argentina hasta 1945. De esta forma, los defensores de la reforma trataron de imponer constitucionalmente la doctrina partidaria mediante otra concepción del derecho: se trataba de una completa recodificación conforme los principios del Partido. ${ }^{42}$

\section{La defensa político-intelectual a la iniciativa peronista: argumentos $y$ conceptos}

Hubo distintos tipos de argumentos que los intelectuales y políticos peronistas siguieron para defender la reforma constitucional. En sus discursos, Perón había realizado una síntesis de ellos. Mediante la reforma, aseguraba "afianzar el bienestar y la prosperidad del pueblo argentino" y la "independencia económica”, pues la riqueza, afirmaba, había sido entregada al extranjero. Dichas pautas se lograrían suprimiendo la "economía capitalista de explotación" y quitando el "abuso de propiedad", pues el "individualismo" había formado una sociedad de "egoístas y desalmados" que solo buscaban enriquecerse sin pensar que dicha lógica habría de terminar en un "cataclismo social". ${ }^{43}$

En primer lugar, los incentivadores de la reforma, en su crítica anti imperialista al liberalismo económico, entendían que la Constitución respondía a los intereses de una "minúscula sociedad colonial", defensora de las "teorías individualistas del siglo XVIII", con "preponderancia pastoral", distinta en su concepción a la sociedad basada en los "nuevos principios sociales" que había instaurado Perón. ${ }^{44}$ De esta forma, la "oligarquía"

\footnotetext{
${ }^{42}$ Ver: Ezequiel Abásolo. “El primer peronismo...”, Op. Cit., p. 14 y Miguel A. Rodríguez de la Torre. Ante el problema de la reforma constitucional. Buenos Aires, 1948, pp. 10-12.

43Juan Domingo Perón. "La reforma constitucional asegurará y reforzará nuestro sistema de gobierno". Hechos e Ideas, № 53, Año IX. Buenos Aires, 1948, pp. 145-146.

${ }^{44}$ Ídem, pp. 143-144.
} 


\section{La reforma constitucional de 1949: influencias y apoyos intelectuales a la iniciativa peronista}

se había encargado de proteger los intereses de las empresas extranjeras y transmitir dicha doctrina a todos los abogados y juristas del país. ${ }^{45}$ No solo denunciaban el carácter extranjero de la Constitución ideada por Juan B. Alberdi, sino que estaban en contra de la "servidumbre intelectual" que había defendido las "falsas doctrinas" en desmedro del "pueblo". 46

La economía argentina, excepto en el paréntesis reivindicador de Hipólito Yrigoyen, afirmó Scalabrini -un intelectual que no ocupó cargos políticos a lo largo de su vida- había sido entregada al extranjero para que la organizara a su conveniencia. Argumentaba: "la vida económica de estos pueblos quedó inerme, más aún, encadenada de antemano por la dialéctica venal de estos curiales que encubrían con la palabra libertad, que todos amamos, la voluntad de expoliación y la insaciable codicia del capital extranjero".47 Así, la Constitución de 1949 se convirtió en un escrito anti imperialista que defendía los intereses económicos argentinos frente al "apoderamiento" de la Constitución por parte de la "oligarquía". 48

La editorial de la revista Hechos e Ideas iba más allá. Alberdi no era, afirmaba, un "hombre apasionado por las doctrinas filosóficas o políticas", no proponía solo un "cuerpo jurídico fundado en los principios individualistas", sino un conjunto de "normas practicas destinadas a alentar por todos los medios el incremento demográfico de lo que el juzgaba un desierto y la inversión de capitales extranjeros" basándose en su "mentalidad firmemente anti democrática". ${ }^{4}$

En sintonía con la publicación peronista, John W. Cooke, diputado por la Capital Federal y figura trascendental para el pensamiento peronista, destacó el "problema de la libre navegación de los ríos" que, afirmaba, había incentivado Alberdi. A sus ojos, el liberalismo económico era una "entrega de la soberanía", una "vergüenza nacional", propiciada por el imperialismo extranjero y la "rapacidad europea". Dichas ideas mostraban la falta de "confianza en lo nacional, en lo nativo", cuando en realidad, sostenía, la Constitución debía estar ajustada a la "realidad del país". ${ }^{0}$

Por dichas razones, y en segundo lugar, los políticos e intelectuales peronistas entendían que era momento de evolucionar legalmente para continuar con la "revolución", aquella que, en palabras del coronel Juan F. Castro, secretario de Transportes de la Nación, había dado un "estado de alegría" a la sociedad.51 Las leyes, afirmaba Scalabrini, eran fruto de la

\footnotetext{
${ }^{45}$ Juan F. Castro, Secretario de transportes de la Nación hacia 1948, consideraba que la constitución de 1853 había dado "libertad y derecho a los capitales extranjeros que cayeron en nuestras playas". Así, defender dicho escrito era "estar en contra de la patria". Juan F. Castro. Reforma de la Constitución. Buenos Aires, 1948, p. 12.

46"Glosas políticas". Hechos e Ideas, № 53, Año IX. Buenos Aires, 1948, pp. 131-134.

${ }^{47}$ Raúl Scalabrini Ortiz. El capital, el hombre y la propiedad en la vieja y en la nueva Constitución. Buenos Aires, Reconquista, 1948, p. 14.

48Ver: John William Cooke. "La Constitución debe ajustarse a la realidad del país". Hechos e Ideas, № 53, Año IX. Buenos Aires, 1948, pp. 169 y 171.

49"Glosas políticas”, Op. Cit., pp. 135 y 276.

50John William Cooke. “La Constitución debe...”, Op. Cit., pp. 170 y 173.

${ }^{51}$ El secretario de Transportes consideraba que la Constitución de 1853 había sido "buena en su época" al garantizar las libertades políticas ciudadanas, pero que nada había estipulado sobre los derechos del trabajador. Ver: Juan F. Castro. Reforma de la..., Op. Cit., p. 10-12 y Vicente Bagnasco. "El
} 
"experiencia del pasado que la razón intentó imponer como norma al porvenir" y, como la vida se basaba en el constante cambio, la Constitución debía adaptarse a las nuevas circunstancias políticas. ${ }^{52}$ En definitiva, para nuestro autor, la reforma era solo la "vindicación de los derechos que debieron amparar al hombre argentino del siglo pasado y del siglo presente".53 De todas formas, afirmaba Cooke, la Constitución tenía incorporado lo que tenía de permanente el espíritu argentino, la parte del alma nacional que no estaba "afectada por lo contingente del devenir histórico: el sentido democrático e igualitario y el respeto del hombre como valor humano". ${ }^{4}$

A pesar de los argumentos anteriormente mencionados, Palacio dudaba de que en el pasado la Constitución hubiese sido funcional a los intereses de la Nación: había sido pensada para los extranjeros imitando al modelo estadounidense. Siguiendo una tercera línea de argumentos críticos hacia la Constitución decimonónica, desaprobaba las ideas de Alberdi por considerarlo un detractor de la cultura española y el cristianismo. Según afirmaba, buscó cambiar la raza argentina e imponer las doctrinas liberales europeas. ${ }^{55}$ Así, Alberdi era para dicho escritor un "denostador de la estirpe hispánica y de la gloria militar" que había propuesto a sus "compatriotas como modelos de humanidad superior".56 Joaquín Díaz de Vivar, diputado correntino y vicepresidente de la Cámara baja entre 1947 y 1955, tuvo ideas similares a las de Palacio, pues destacaba, siguiendo al jurista e ideólogo de la Constitución de 1949, ligado a la agrupación FORJA, Arturo

porqué de las reformas a la Constitución". Hechos e Ideas, № 53, Año IX. Buenos Aires, 1948, pp. 155156.

${ }^{52}$ Esta idea era compartida por diferentes intelectuales y políticos. Juan Atilio Bramuglia marcaba la imposibilidad de sostener una Constitución inmutable y la necesidad de realizar modificaciones, incluso por las vías "irregulares" como una revolución o un golpe de estado. Ángel G. Borlenghi creía necesario corregir los "excesos antisociales" y reconocer los derechos inherentes a la personalidad humana. Julio Herrera afirmaba que la antigua Constitución debía considerarse con "amor filial", el cual, "como "buena madre" nos había indicado el camino a seguir por la "grandeza del país". Miguel A. Tanco. "Las constituciones son leyes humanas y, como tales, no son inmutables". Hechos e Ideas, № 53, Año IX. Buenos Aires, 1948, p. 226, Ángel G. Borlenghi. "La opinión del Gobierno ante las reformas de la Constitución". Hechos e Ideas, № 53, Año IX. Buenos Aires, 1948, pp. 186 y 189-190, Julio Herrera. "La evolución social y económica impone la reforma constitucional". Hechos e Ideas, № 53, Año IX. Buenos Aires, 1948, p. 196, Lorenzo Soler (h). "La Constitución del 53, ya cumplió su misión en nuestra vida institucional”. Hechos e Ideas, № 53, Año IX. Buenos Aires, 1948, p. 231, Juan Domingo Perón. "La reforma...", Op. Cit., pp. 143-144, Juan Atilio Bramuglia. "Hay que abandonar el sistema individualista en las reformas constitucionales". Hechos e Ideas, № 53, Año IX. Buenos Aires, 1948, p. 214, Belisario Gache Pirán. "Los problemas de hoy no pudo preverlos la Constitución del 53". Hechos e Ideas, № 53, Año IX. Buenos Aires, 1948, p. 219, Raúl Scalabrini Ortiz. El capital..., Op. Cit,, p. 4.

${ }^{53}$ Pablo Ramella, Armando G. Antille y Angel G. Borlenghi, entre otros, también hicieron hincapié en la orientación jurídica con "excesivo individualismo" que tenía la antigua Constitución, producto de la influencia de las ideas de Jean-Jacques Rousseau y su "contrato social". Tal como afirmaba Ibarguren, los intelectuales peronistas argumentaba que la legislación vigente hasta 1949 había seguido los conceptos individualistas de la Revolución francesa. Ver: Juan Atilio Bramuglia. "Hay que abandonar...”, Op. Cit., p. 213, Pablo A. Ramella. “Toda Constitución...”, Op. Cit., p. 182, Ángel G. Borlenghi. "La opinión del...", Op. Cit., p. 188, Armando G. Antille. "Razones que fundamentan la reforma constitucional”. Hechos e Ideas, № 53, Año IX. Buenos Aires, 1948, p. 235, Raúl Scalabrini Ortiz. El capital..., Op. Cit., p. 9.

${ }^{54}$ John William Cooke. “La Constitución debe...”, Op. Cit., p. 198.

${ }^{55}$ Ernesto Palacio. "¿Se trata de elaborar, al fin, una Constitución para los argentinos?”. Hechos e Ideas, № 54, Año IX. Buenos Aires, 1948, p. 280.

56Ídem, p. 281. 


\section{La reforma constitucional de 1949: influencias y apoyos intelectuales a la iniciativa peronista}

Sampay, que el "tradicionalismo hispánico" había sido interferido por el espíritu de la Constitución de 1853, dando como resultado un "progresismo liberal" que exaltaba las posibilidades de la "fe" en la "razón".57

Para Sampay, la Revolución de Mayo había sido una ruptura en el pensamiento hispánico, entendiendo a aquel, desde lo fundamental, “como la antípoda del pensamiento racional-individualista vigente en el resto de Europa".58 El Estado, destacó, era "un ente de cultura" que estructuraba la vida y como tal, representaba una realidad social con un determinado contenido y finalidad. Se oponía a las ideas "cientificistas del Renacimiento" que, afirmaba, marcaban una idea naturalista del Estado, aquella que persistía en los "materialistas", representados por geopolíticos, biólogos y otros tipos de científicos. ${ }^{59}$ El Estado, continuaba, había "nacido realmente de la religión", razón por la que denostaba a la Constitución liberal de 1853, pues, "en su soberbia positivista", había despreciado a la teología e ignorado los preceptos cristianos, aquellos que Palacio ligaba al hispanismo. ${ }^{60}$ Por dichos motivos, afirmaba Sampay: "Los argentinos debemos aleccionarnos en la experiencia histórica acumulada. Por un privilegio insospechado -¡la paradoja del rezago hispanoamericano!- todavía es dado hacerlo, pues aquí sazonan con retardo los últimos frutos de la desintegración moderna". 61

Siguiendo su lógica hispánico-católica, Sampay hacía un llamado para reconsiderar el pasado argentino en relación a España, pues creía que la colonización española había respondido al "móvil decisivo" de "mantener y acrecentar la Cristiandad", es decir "de llegar a la unidad ecuménica en la universitas christiana". No podía dudarse, afirmaba, del firme designio y la consiguiente decisión política de hacer de España el guion espiritual de un mundo que perdía su unidad moral".62

Por el contrario, Scalabrini no consideraba que los argentinos debían exaltar la colonización española, pues había sido una forma de imperialismo similar a la inglesa. Afirmaba que, mediante la explotación económica y del predominio excluyente del extranjero en la instrucción pública, el "oro americano" había sido "hurtado a los aztecas y a los incas por la violencia descarada y franca". Si "Pizarro y Hernán Cortés hubieran usado los medios financieros modernos, se habrían apropiado del oro como rendimiento del capital extranjero invertido en financiar las empresas de conquista".63 Tampoco creía, a diferencia del ministro del Interior Ángel G. Borlenghi y Sampay, que los derechos a incorporar en la Constitución estuvieran inspirados en los preceptos del cristianismo. Su

\footnotetext{
57Joaquín Díaz de Vivar. "La Carta de Filadelfia y la Constitución Argentina". Hechos e Ideas, № 53, Año IX. Buenos Aires, 1948, p. 165.

${ }^{58}$ Arturo E. Sampay. La crisis del Estado de derecho liberal-burgués. Buenos Aires, Losada, 1942, p. 13.

59 Para este tema, ver: Arturo E. Sampay. Las Constituciones de la Argentina (1810-1972). Buenos Aires, Eudeba, 1975.

60 Ídem, pp. 11, 27, 38 y 41.

61 Ídem, p. 12.

62 Ídem, p. 14.

${ }^{63}$ Es curioso que el senador de la provincia de Jujuy Miguel A. Tanco exaltara la imagen de Hernán Cortés y el coraje de Francisco Pizarro en la conquista de América. Miguel A. Tanco. "Las constituciones...", Op. Cit., p. 223, Raúl Scalabrini Ortiz. El capital..., Op. Cit., p. 16.
} 
idea de sociedad fraternal y orgánica se basaban en las consecuencias negativas que, argumentaba, el seguimiento de políticas liberales había generado en la sociedad argentina. ${ }^{64}$

Un cuarto corpus de argumentos importantes a destacar son aquellos que resultaron críticos de la influencia que tuvo la Constitución estadounidense 65 en el escrito decimonónico. Cooke destacaba la poca importancia que la Constitución de 1853 daba a la representación popular, cuestión que también estacaba la revista Hechos e Ideas tomando en cuenta las críticas al constitucionalismo estadounidense que habían realizado el historiador Charles A. Bears. ${ }^{66}$ Dicha postura, afirmaba Cooke, había surgido al imitar el modelo estadounidense, pues en el seno de la Convención de Filadelfia no había tenido popularidad la representación de las mayorías. ${ }^{67}$

Díaz de Vivar tuvo apreciaciones similares. La Junta de Filadelfia, afirmó, solo representaba a los ciudadanos "prominentes" y no había sido preparada mediante la consulta de la opinión pública. La "minoría americana" y "anti democrática", sostuvo, consolidó un orden económico que solo a ellos beneficiaba. ${ }^{68}$ De esta forma, siguiendo su relato, el supuesto carácter anti democrático de la Constitución de 1853 era consecuencia de los modelos elegidos para su redacción. ${ }^{69}$

Un quinto corpus de argumentos se destacaban por el carácter reformista -lindando con el clasismo- que proponían para el nuevo escrito constitucional, especialmente en relación a la idea de propiedad privada. La "economía liberal", afirmaban desde Hechos e ideas, alejaba cada vez más al "trabajador de la posesión de los bienes de producción y lo esclavizaba" solo para defender, "bajo el imperio de un poder económico", la "ingenua garantía de inviolabilidad de la propiedad"70 Argumentos similares escribió Scalabrini. Con una idea de país precisa, argumentó que se había abonada con la sangre de los nativos la tierra a fin de crear los inmensos latifundios: sólo para los europeos cobraban vigencia los principios "protectores de la propiedad" privada. ${ }^{71}$ Proponía suspender su

\footnotetext{
${ }^{64}$ Bramuglia también destacó la participación de la Iglesia Católica Apostólica Romana en la cultura argentina. Juan Atilio Bramuglia. "Hay que abandonar...", Op. Cit., p. 217, Ángel G. Borlenghi. "La opinión del Gobierno...”, Op. Cit., p. 190 y Raúl Scalabrini Ortiz. El capital..., Op. Cit., pp. 13 y 18

${ }^{65}$ Para este tema es conveniente ver: Charles A. Beard. Una interpretación económica de la constitución de EEUU. Buenos Aires Arayú, 1953, Peter Linebaugh y Marcus Rediker. "Una 'cuadrilla variopinta' en la revolución americana", en La hidra de la Revolución. Marineros, esclavos y campesinos en la historia oculta del Atlántico. Barcelona, Crítica, 2005, pp. 203-285.

${ }^{66}$ Charles A. Beard fue un historiador crítico de las instituciones políticas estadounidenses cuyos argumentos hacían hincapié en los conflictos y cambios socioeconómicos. "Glosas políticas". Op. Cit., p. 136.

${ }^{67}$ John William Cooke. “La Constitución debe...”, Op. Cit., p. 171.

${ }^{68}$ Joaquín Díaz de Vivar. "La Carta de Filadelfia...”, Op. Cit., p. 164. .

${ }^{69}$ En relación a la democracia y la representatividad política, Cooke proponía derogar la "prohibición de reelegir al presidente", siendo uno de los pocos diputados que tuvo argumentos respecto a dicha iniciativa. Para el intelectual, aquella era una "simple garantía" que no había funcionado porque el fraude no presuponía que un hombre lo hiciera en su propio beneficio. De esta forma, exculpaba a Perón si es que fuera a trasgredir la ley en caso de no ser sancionada la posibilidad de reelección presidencial.Ver: John William Cooke. “La Constitución debe...”, Op. Cit., p. 174.

70"Glosas políticas”. Op. Cit., p. 138.

${ }^{71}$ Raúl Scalabrini Ortiz. El capital..., Op. Cit., pp. 17-18.
} 


\section{La reforma constitucional de 1949: influencias y apoyos intelectuales a la iniciativa peronista}

inviolabilidad mientras fuese con fines de utilidad pública, aspecto que, destacaba, Alberdi había sido precavido en mantener jurídicamente inapelable. ${ }^{72}$

Varios senadores y ministros afirmaban que la reforma debía quitar la "amplitud" del derecho de propiedad, ${ }^{73}$ pues solo había servido para afianzar la riqueza de "los menos con el abuso del derecho de propiedad y las prebendas que a él" se asociaban. La propiedad, afirmaba el ministro de Relaciones Exteriores Juan Atilio Bramuglia, debía actuar exclusivamente en función social. ${ }^{74}$ Oscar Tascheret, senador nacional por la provincia de San Juan, incluso afirmaba que siendo un "elemento natural y pasivo en la producción", debía recibir un tratamiento cuidadoso pero más equitativo. En ese sentido, destacaba la medida rivadaviana que cedía la tierra en enfiteusis, un "elemento científico" que había sido "sepultado por el egoísmo de algunas generaciones de hombres".75

Las políticas que incentivaban la intervención estatal en la economía, sexto eje de argumentos que debemos destacar respecto a la reforma, recibieron un fuerte respaldo entre los intelectuales, senadores y diputados peronistas. Respecto a dicho punto, Cooke se mostraba como un fiel seguidor de Ibarguren. Creía que la intervención del Estado era necesaria en todos los orden de la vida, excepto en la "personalidad intima del individuo". Según su perspectiva, era una falacia que la libertad individual presuponía la libertad económica, pues la democracia política y el capitalismo no eran silogismos. Los peronistas, aclaraba, se negaban a vivir en "adulterio mental con lo extranjero".76 Las constituciones del siglo XIX, afirmaba Díaz de Vivar en consonancia con Cooke, sólo habían protegido los intereses burgueses e incentivado la lucha por la riqueza material. ${ }^{77}$ La masa popular, destacaba Borlenghi, "durante mucho tiempo oprimida o engañada", luchaba "reciamente por la conquista de sus derechos" contra el individualismo filosófico y egoísta. ${ }^{78}$ Era necesario, argumentaba Tascheret, "detener a tiempo" la lucha entre capital y trabajo mediante la acción del Estado, pues de no lograrse dicho cometido la humanidad sucumbiría en la "miseria y despotismo".79

En definitiva, la necesidad de establecer una reforma e incentivar la intervención estatal en la economía, según Sampay, se reducía a la "angustiosa ansia contemporánea por generar una sociedad en que la dignidad del hombre" fuese defendida de forma completa. Para dicho fin, era necesario instaurar distintas políticas públicas que tuvieran en cuenta "el pleno empleo", pero también aquellos bienes materiales que eran necesarios para el

\footnotetext{
72Ídem, p. 21.

${ }^{73}$ Tras la reforma, el Artículo 38 afirmaba: "La propiedad privada tiene una función social y, en consecuencia, estará sometida a las obligaciones que establezca la ley con fines de bien común”. Ver: Constitución de la Nación Argentina. Buenos Aires, Publicación de la Secretaria del H. Senado de la Nación, 1949, p. 37.

${ }^{74}$ Juan Atilio Bramuglia. "Hay que abandonar...", Op. Cit., p. 216.

${ }^{75}$ Oscar Tascheret. "El contenido social en las constituciones modernas", Hechos e Ideas, № 53, Año IX. Buenos Aires, 1948, pp. 208-209.

76John William Cooke. “La Constitución debe...”, Op. Cit., pp. 174-176.

77Joaquín Díaz de Vivar. “La Carta de Filadelfia...”, Op. Cit., p. 162.

${ }^{78}$ De nada servían los derechos teóricos, afirmaba, si el medio o la sociedad estaban atravesados por “el peso de la minoría”. Ángel G. Borlenghi. “La opinión del Gobierno...”, Op. Cit., pp. 186 y 188.

${ }^{79}$ Oscar Tascheret. "El contenido social...”, Op. Cit., p. 208.
} 


\section{Gonzalo Rubio García}

desarrollo humano. ${ }^{80} \mathrm{El}$ nuevo orden guardaba una lógica económica distinta, pues la imposibilidad de explotar laboralmente a los hombres por el afán de lucro previsto en la constitución en el Artículo 35, sumado a la doble función personal y social que adquiría la propiedad, cambiaban, para Sampay, radicalmente los ejes en que se articulaba la sociedad. ${ }^{81}$

Perón se mostraba como un defensor del capitalismo intervencionista y la propiedad privada, siempre y cuando no desestabilizaran el orden social. Sus palabras trasmitían una lógica nacionalista desde un punto básico: la unidad nacional de la población era importante para lograr la armonía entre los diferentes grupos sociales. Por dicha razón, buscaba que la "cooperación reemplace a la lucha" en todos los aspectos culturales. ${ }^{82}$ Aunque en esa lógica no había lugar para los "otros", aquellos que habían protegido los "intereses extranjeros" y los "abusos del individualismo" hacia el trabajador.83 Mediante una política que distribuyera la riqueza, respaldada por la nueva constitución, se debía promover un régimen en el que las fortunas estuvieran subordinadas al "derecho y a la moral" a fin de lograr la plena economía social y la protección política, desde el Estado, de los más desfavorecidos. ${ }^{84}$

En relación a las posturas que defendían la intervención estatal en la sociedad, y en séptimo lugar, debemos destacar los argumentos de Tascheret, ya que sólo aquel hizo hincapié en los temas relacionados a la salud de la población al momento de reformar la Constitución. Dicho senador era afín al ambiente de la medicina, razón por la cual entendía a la "salud" como una "condición fundamental para la felicidad y bienestar de la humanidad", siendo dicho punto, la "alegría", otra importante preocupación que la Constitución debía resguardar. $85 \mathrm{Si}$ bien el antiguo escrito buscó ocuparse de la "libertad espiritual", tras la reforma, al cambiar las consideraciones sobre el cuerpo humano, debía ser distinta la importancia que el Estado daba al bienestar de los individuos. Este sentido muestra la concepción orgánica que el peronismo tenía de la sociedad y la importancia que cobraba amparar a los ciudadanos ante cualquier aspecto de la vida.

En octavo lugar, hubo otros argumentos que hacían hincapié en los cambios del sistema institucional que podría traer la reforma. Perón aseguraba que su Gobierno había reforzado el republicanismo -suprimiendo la "oligarquía plutocrática-, "eliminado el fraude" que trababa el desarrollo del régimen representativo y estimulado el federalismo político al incentivar las economías regionales. ${ }^{86}$

De cualquier forma, los históricos reclamos federales de los senadores generaban ciertas fisuras dentro del peronismo. El senador jujeño Miguel A. Tanco destacaba el unitarismo vigente en la Argentina, pues las provincias respondían a un sistema mixto entre el unitario y el federal en el cual no podían dictar leyes convenientes al aprovechamiento de

\footnotetext{
${ }^{80}$ Arturo E. Sampay. La reforma constitucional. La Plata, Laboremus, MCMXLIX, pp. 38-44.

81 Ídem, p. 47.

82Juan Domingo Perón. “La reforma...”, Op. Cit., p. 146.

83Ídem, p. 147.

${ }^{84}$ Ver, además: Miguel A. Tanco. "Las constituciones...", Op. Cit., p. 224, Juan Atilio Bramuglia. "Hay que abandonar...”, Op. Cit., p. 212, Belisario Gache Pirán. “Los problemas...”, Op. Cit., p. 220.

${ }^{85}$ Oscar Tascheret. "El contenido social...", Op. Cit., p. 199.

${ }^{86}$ Miguel A. Tanco. "Las constituciones...", Op. Cit., p. 224.
} 


\section{La reforma constitucional de 1949: influencias y apoyos intelectuales a la iniciativa peronista}

su riqueza. A diferencia de Cooke, Scalabrini y Palacio, aconsejaba seguir el ejemplo de Estados Unidos por su "federalismo integral".87 En similares términos se expresó Alejandro Mathus Hoyos, senador por la provincia de Mendoza y delegado en 1940 de la Convención Nacional de la Unión Cívica Radical, quien defendía la autonomía de las provincias y pedía "darle jerarquía constitucional a las normas" que regulaban la "proporcionalidad de la distribución impositiva" a partir de estudios técnicos. De esa forma, aclaraba, se podría cumplir con la "doctrina del Pacto Federal de 1831 y del Acuerdo de San Nicolás". Para Hoyos, los "estados federales argentinos" 88 esperaban conseguir un real federalismo y no una deformación de dicho sistema. ${ }^{89}$

En este punto, es interesante tener en cuenta la crítica a la reforma que escribió Gabriel Del Mazo, representante de la Unión Cívica Radical y fundador de la agrupación FORJA junto a Jauretche y Manzi, entre otros. Sus argumentos hacían referencia al debilitamiento de las formas republicanas y federales que representaba la reforma, pues afirmaban el "discrecionalismo presidencial"90 e invadía la "órbita de los poderes" que las provincias argentinas habían reservado tras el pacto federal contra el "autocratismo centralista".91

El orden y la representación federal que invocaba la constitución de 1853, aseguraba Del Mazo, no habían sido cumplidos. A sus ojos, la política nacional debía fundarse en la autonomía de los Estados respecto al gobierno federal. ${ }^{92}$ Los "Estados provinciales",93 afirmaba, estaban trabados en su desarrollo por las intervenciones centralistas, problema que empeoraría con la reforma constitucional. ${ }^{94}$

En noveno lugar, es necesario destacar aquellas posturas relacionadas a la Historia que seguían la dicotomía entre el "pueblo" y la "oligarquía", haciendo hincapié en distintas figuras y acontecimientos históricos que habrían presagiado y justificado la reforma

\footnotetext{
87Ídem, pp. 224-226.

${ }^{88}$ Nos parece interesante dicha denominación por los comunes errores en que se ha incurrido históricamente al reivindicar al sistema federal. Ver: José Carlos Chiaramonte. Raíces históricas del federalismo latinoamericano. Buenos Aires, Sudamericana, 2016, pp. 105-155.

${ }^{89} \mathrm{El}$ senador de La Rioja, Cesar Vallejos, citó a la figura del General José Justo de Urquiza para reafirmar la concepción "republicana, representativa y federal" que debía guardar la nueva constitución. De cualquier forma, tal como Chiaramonte ha demostrado, hacia 1855 Alberdi estaba preocupado por la decadencia del confederacionalismo: quería demostrar que "Buenos Aires no era toda la República". Así, es probable que los senadores no tuvieran como punto de ataque, al menos en este caso, la figura de Alberdi. Ver: Cesar Vallejos. "Puntualizando aspectos básicos en la reforma constitucional". Hechos e Ideas, № 53, Año IX. Buenos Aires, 1948, pp. 254-255 y Alejandro Mathus Hoyos. "Algunas reflexiones sobre reformas constitucionales". Hechos e Ideas, № 53, Año IX. Buenos Aires, 1948, pp. 246-247 y José Carlos Chiaramonte. "Alberdi y el sentido de su federalismo". PolHIs, № 17, Año 9, 2016, pp. 13-14.

${ }^{90}$ Del Mazo afirmaba que el presidente de turno tendría la posibilidad de legislar en materia de gastos público, pues el Congreso no habría de tener participación en la formación y estructura del presupuesto, incentivando la censura y el centralismo. Gabriel Del Mazo. El federalismo argentino y la reforma de la Constitución. Buenos Aires, Nemesio A. Ferrari, 1949, pp. 17 y 27.

91 Ídem, p. 3.

92Ídem, p. 5.

93Para Del Mazo la "nación" como expresión de la voluntad de los "pueblos a mantenerse unidos" tenía existencia anterior a la Constitucional Nacional. Así, las provincias continuaban siendo Estados, conservando sus poderes, excepto aquellos que habían delegado al Estado Nacional creado por estas. Ídem, pp. 21-23.

${ }^{94}$ Ídem, p. 36.
} 


\section{Gonzalo Rubio García}

constitucional. Aunque dichos argumentos fueron mayormente sostenidos por los intelectuales peronistas, como Scalabrini, Gálvez y García Mellid, antes que por los distintos senadores y diputados presentes en el Congreso, no debemos dejar de mencionar que había una constante retroalimentación entre las figuras de ambas esferas, pues los argumentos utilizados por unos y otros eran compartidos y se complementaban. Scalabrini, en particular, afirmaba que el hombre porteño había procurado impedir que el capital extranjero interfiriera en el manejo de la función pública sin lograrlo. ${ }^{95}$ Dicho autor encontraba los argumentos para apoyar la reforma constitucional en las proclamas de Mariano Moreno, "algunas intenciones de Dorrego" y los "relámpagos de inspiración de Juan Manuel de Rosas". Las ideas de aquellas figuras habían caído abatidas por el conclave constituyente de 1853, pues de "ninguna manera expresaban la voluntad del pueblo de la Nación Argentina". ${ }^{96}$ De esta forma, tal como habían entendido otros intelectuales, nuestro autor reducía las posibilidades a dos maneras de entender el país, es decir, dos caminos: extranjerizante o nacionalista. ${ }^{97}$ La Constitución de 1853 estaba al "servicio integral de las conveniencias del capital extranjero", mientras que las reformas constitucionales que buscaba implantar Perón -basadas para Scalabrini en la línea ideológica planteada por Moreno e Yrigoyen- habrían de hacer al texto jurídico más acorde al "respeto del hombre, de sus trabajos y de sus sueños".98

De cualquier forma, la relación entre Yrigoyen y Perón había sido establecida por García Mellid y Gálvez con anterioridad a la publicación de Yrigoyen y Perón, identidad de una línea histórica (1948), obra de Scalabrini en que defendió la filiación de Perón con el líder radical. Gálvez había escrito un artículo, publicado en el periódico El pueblo el 13 de agosto de 1944, en donde afirmaba: "el coronel Perón es un nuevo Yrigoyen".99 De allí a establecer la línea Rosas-Yrigoyen-Perón había un solo paso, pues con anterioridad había establecido la relación Yrigoyen-Rosas. De hecho, Gálvez denostaba en el citado artículo al Congreso, pues -fiel a su filo-fascismo- consideraba al organismo una traba para el desarrollo de políticas favorables a los obreros. Al respecto, afirmaba que las iniciativas que habían tenido Joaquín V. González e Yrigoyen no prosperaron debido a que las cámaras no las habían tomado en cuenta. Perón, por el contrario, prescindía de la "politiquería" del Congreso y daba beneficios a los trabajadores mediante "decretos rápidamente puestos en práctica".100

Hacia mediados de la década de 1940, los forjistas querían establecer una relación directa entre Yrigoyen y Perón, filiación que servía al líder justicialista para engrosar su base

\footnotetext{
${ }^{95}$ Raúl Scalabrini Ortiz. El capital..., Op. Cit, p. 7.

${ }^{96}$ Ídem, p. 11.

${ }^{97}$ Herrera argumentó algo similar: Los derechos del "pueblo", afirmó, encontraban su sentido "en los momentos iniciales de Mayo". La "argentinidad" encontraba cause en la "expresión viviente de los ideales que alentaron a nuestros próceres", siendo Perón y su "revolución" los representantes de esos ideales hacia finales de la década de 1940. Ver: Julio Herrera. "La evolución social...", Op. Cit., p. 196. ${ }^{98}$ Cooke también tuvo dicha noción de la historia, pues las "masas populares" habían llegado al poder por el sufragio universal solo con Perón e Yrigoyen. John William Cooke. "La Constitución debe...", Op. Cit., p. 173, Raúl Scalabrini Ortiz. El capital..., Op. Cit., pp. 12 y 23.

${ }^{99}$ Manuel Gálvez. "La obra social que desarrolla el Coronel Perón", en Coronel Juan Perón, El pueblo quiere saber de qué se trata. Buenos Aires, 1944, p. 8.

100Ídem, pp. 8-9
} 


\section{La reforma constitucional de 1949: influencias y apoyos intelectuales a la iniciativa peronista}

partidaria. García Mellid -un intelectual-político que había formado parte en la fundación de FORJA- en su libro Montoneras y caudillos en la historia Argentina (1946), también realizó un análisis sobre la "conciencia histórica nacional", poniendo su eje en el "pueblo" como sujeto y centro de la historia. Allí, delineó un esquema en el cual distintos autores, sucesos y gobiernos habrían respondido a los intereses nacionales, mientras que otros habrían sido parte de la "oligarquía" y sus pretensiones por someter a los "argentinos".101 García Mellid consideraba que la historia había sido escrita por los "liberales" y "unitarios" de la "ilustración" que defendiendo la "historia oficial" habían luchado contra la "justicia verdadera" por la que peleaban los "caudillos", representados por Juan Manuel de Rosas, Yrigoyen ${ }^{102}$ y Perón, según la época que el autor citara. Historiadores como Ernesto Quesada o Estanislao Zeballos, afirmaba, habían buscado desarmar la "historia oficial" mitrista de índole eurocentrista, característica que incluso había compartido "un historiador de mentalidad oligárquica como Emilio Ravignani".103

La "visión del pueblo", única a pesar de los diferentes contextos de época en que vivieron todos los personajes que citaba el autor, habría estado presente en las manifestaciones de sus caudillos. Por esta razón, los períodos históricos cobraban poca relevancia, pues los intereses de los dos supuestos grupos -el "pueblo", representado por los "gauchos", "compadritos" y la "chusma", frente a la "oligarquía"-104 que delinearon los autores para sus relatos habrían estado determinados desde la Revolución de Mayo. ${ }^{105}$

\section{Conclusión}

Como hemos podido observar a lo largo del escrito, hubo distintos tipos de argumentos utilizados para defender la reforma constitucional de 1949 cuya raíz ideológica era similar. De todas formas, a un nivel general, podemos destacar la crítica al liberalismo que los partidarios peronistas asimilaban al imaginario de la Revolución francesa y a la cultura estadounidense decimonónica. Dicho punto de partida, afirmaban, había generado ideas contrarias a la cultura argentina, logrando un desacertado camino para el desarrollo cultural, político y económico del país.

La reforma no sólo representaba para los peronistas una nueva forma de entender la sociedad, pues otorgaba al Estado un papel importante para remediar los males del capitalismo y proteger a los individuos más vulnerables, sino también un tipo de redención cultural anti imperialista. Dicho cambio cultural -aquello que los diputados entendían como un cambio político y social del país surgido de la "revolución peronista"-

\footnotetext{
${ }^{101}$ Atilio García Mellid. Montoneras y caudillos en la historia argentina. Buenos Aires, Eudeba, 1985, pp. 26-27, 30-31, 56 y 58.

${ }^{102}$ Atilio García Mellid. "Alem, Yrigoyen y Perón: símbolos de las muchedumbres argentinas”. Hechos e Ideas, № 54, Año IX. Buenos Aires, 1948, p. 286.

${ }^{103}$ Atilio García Mellid. Montoneras y caudillos..., Op. Cit., pp. 11, 27, 31, 37, 43, 56 y 63 y Atilio García

Mellid. “Alem, Yrigoyen...”, Op. Cit., pp. 298-299.

${ }^{104}$ Ídem, p. 287.

${ }^{105}$ Atilio García Mellid. Montoneras y caudillos..., Op. Cit., pp. 81, 83, 86, 93-95 y 107-111.
} 


\section{Gonzalo Rubio García}

prometía hacer hincapié en las necesidades y designios nacionales, aunque aquello que definía a los argentinos era representando bajo diferentes imaginarios sociales.

En relación al punto anterior, podemos afirmar que los argumentos esgrimidos por los intelectuales y políticos peronistas mostraban las diferentes cosmovisiones que guardaba el movimiento. Dicha reflexión es posible observarla mediante los casos de Scalabrini, Palacio y Sampay, escritores que tenían apreciaciones distintas sobre el papel que había jugado España y el catolicismo -el afamado hispanismo católico- en la cultura argentina. Palacio y Sampay, entre otros, a diferencia de Scalabrini, creían que la esencia nacional se debía buscar en la influencia que había sabido tener la cultura española en la Argentina, perdida desde la llegada al poder de los "liberales" -como por ejemplo Alberdi o Bernardino Rivadavia- con sus ideas "europeas", postura que no compartía Scalabrini. $\mathrm{Si}$ nos remitimos a los argumentos que anteriormente hemos expuesto, podremos comprobar que las consideraciones sobre la incidencia de la cultura española son muestra de la idea de nación que cada autor guardaba para la Argentina.

Los argumentos para reformar la Constitución también hacían hincapié en la crítica a la "oligarquía". Dicho grupo, afirmaban, había utilizado la vieja Constitución para enriquecerse -siguiendo su axiología "crudamente materialista"106 y anti espiritual- y beneficiar a los capitales extranjeros mediante la defensa del liberalismo decimonónico, dejando al "pueblo" viviendo en la miseria y sin ninguna posibilidad de asistencia por parte del Estado: la lucha por establecer la reforma era a sus ojos una disputa entre "pueblo" y “oligarquía”. En este sentido, los argumentos que mostraban los diputados iban en consonancia con aquellos que había defendido el revisionismo histórico en torno a la década de 1930. Sin embargo, dicho punto no implica que el revisionismo haya sido adoptado como relato histórico por el peronismo, pues no formaba parte del conjunto de posiciones oficiales. ${ }^{107}$

Debemos destacar el uso común por algunos diputados ${ }^{108}$ de la crítica al materialismo en defensa de la espiritualidad. Dicha postura era común entre los nacionalistas. Desde principios del siglo XX, autores como Gálvez habían promovido un renacimiento espiritual crítico del cosmopolitismo cultural que asociaban al positivismo. En aquel contexto de época, la primera visita de José Ortega y Gasset en 1916 a Latinoamérica marcó profundamente a los anti positivistas argentinos. Dicho intelectual hablaba de la especialidad espiritualidad de la región, idea que José Enrique Rodó continuó al rechazar los aspectos utilitarios del materialismo. ${ }^{109}$ De esta forma, podemos observar que los argumentos contra el liberalismo y el materialismo que formaron parte de la cosmovisión peronista encontraban antecedentes en intelectuales del pasado inmediato. ${ }^{110}$

\footnotetext{
106John William Cooke. “La Constitución debe...”, Op. Cit., p. 169.

${ }^{107}$ Alejandro Cattaruzza. "El revisionismo: Itinerario de cuatro décadas", en Alejandro Cattaruzza y Alejandro Eujanián, Políticas de la historia: Argentina 1860-1960. Buenos Aires, Alianza, 2003, p.167. 108Ver: Vicente Bagnasco. “El porqué...”, Op. Cit., p. 156.

${ }^{109}$ José Enrique Rodó. Ariel. Buenos Aires, Cervantes, 1920, pp. 98 y 103-105.

110Para Gálvez, el liberalismo destruía el espíritu argentino e hispánico debido a su intrínseco materialismo. Manuel Gálvez. El diario de..., Op. Cit., pp. 75, 86, 88, 140, 143 y 148.
} 


\section{La reforma constitucional de 1949: influencias y apoyos intelectuales a la iniciativa peronista}

También debemos hacer notar los claros argumentos en defensa del federalismo que realizaron distintos diputados, dando lugar a sus reivindicaciones de autonomía y los reclamos por una división más favorable de los fondos públicos hacia las provincias. Así, los argumentos anti imperialistas se mezclaban con otro tipo de reclamos que habían tenido lugar a lo largo del siglo XIX. Si bien había unidad entre los peronistas para realizar la reforma de la Constitución, los históricos conflictos entre las provincias y el Estado nacional generaban algunos roces que los separaban políticamente.

\section{Bibliografía}

“Apéndice”. Hechos e Ideas, № 53, Año IX. Buenos Aires, 1948, pp. 269-272.

“Glosas políticas”. Hechos e Ideas, № 53, Año IX. Buenos Aires, 1948, pp. 131-140.

“Glosas políticas”. Hechos e Ideas, № 54, Año IX. Buenos Aires, 1948, pp. 275-279.

Alberto González Arzac. La Constitución justicialista de 1949. Buenos Aires, El Alba, 1973.

Alberto González Arzac. Sampay y la Constitución del futuro, Buenos Aires. Peña Lillo, 1982.

Alejandro Bunge. Una nueva Argentina. Buenos Aires, Hyspamérica, 1984.

Alejandro Cattaruzza. "El revisionismo: Itinerario de cuatro décadas", en Alejandro Cattaruzza y Alejandro Eujanián, Políticas de la historia: Argentina 1860-1960. Buenos Aires, Alianza, 2003, pp. 143-182.

Alejandro Cattaruzza. "Una empresa cultural del primer peronismo: la Revista <<Hechos e Ideas>> (1947-1955)". Revista Complutense de Historia de América, № 19. Madrid, 1993, pp. 269-289.

Alejandro Mathus Hoyos. "Algunas reflexiones sobre reformas constitucionales". Hechos e Ideas, № 53, Año IX. Buenos Aires, 1948, pp. 246-252.

Ana Virginia Persello. Historia del radicalismo. Buenos Aires, Edhasa, 2007.

Ángel G. Borlenghi. "La opinión del Gobierno ante las reformas de la Constitución". Hechos e Ideas, № 53, Año IX. Buenos Aires, 1948, pp. 185-193.

Armando G. Antille. "Razones que fundamentan la reforma constitucional”. Hechos e Ideas, № 53, Año IX. Buenos Aires, 1948, pp. 234-245.

Arturo E. Sampay. La crisis del Estado de derecho liberal-burgués. Buenos Aires, Losada, 1942.

Arturo E. Sampay. La reforma constitucional. La Plata, Laboremus, MCMXLIX. 


\section{Gonzalo Rubio García}

Arturo E. Sampay. Las Constituciones de la Argentina (1810-1972). Buenos Aires, Eudeba, 1975.

Atilio García Mellid. “Alem, Yrigoyen y Perón: símbolos de las muchedumbres argentinas". Hechos e Ideas, № 54, Año IX. Buenos Aires, 1948, pp. 283-302.

Atilio García Mellid. Montoneras y caudillos en la historia argentina. Buenos Aires, Eudeba, 1985.

Belisario Gache Pirán. “Los problemas de hoy no pudo preverlos la Constitución del 53". Hechos e Ideas, № 53, Año IX. Buenos Aires, 1948, pp. 219-221.

Carlos Altamirano. Intelectuales: Notas de investigación sobre una tribu inquieta. Buenos Aires, Siglo XXI, 2013.

Carlos Altamirano. Para un programa de historia intelectual y otros ensayos. Buenos Aires, Siglo XXI, 2005.

Carlos Ibarguren. La inquietud de esta hora: Liberalismo, corporativismo, nacionalismo. Buenos Aires, Boldán, 1934.

Carlos Ibarguren. La reforma constitucional. Buenos Aires, Valerio Abelede, 1948.

Carlos Miguel Herrera. "En los orígenes del constitucionalismo social argentino: Discursos en torno a la Constitución de 1949”. Historia Constitucional, № 15. 2014, pp. 445-469

Cesar Vallejos. "Puntualizando aspectos básicos en la reforma constitucional". Hechos e Ideas, № 53, Año IX. Buenos Aires, 1948, pp. 253-260.

Charles A. Beard. Una interpretación económica de la constitución de EEUU. Buenos Aires Arayú, 1953.

Constitución de la Nación Argentina. Buenos Aires, Publicación de la Secretaria del H. Senado de la Nación, 1949.

Ernesto Palacio. “¿Se trata de elaborar, al fin, una Constitución para los argentinos?”. Hechos e Ideas, № 54, Año IX. Buenos Aires, 1948, pp. 280-282.

Ezequiel Abásolo. "El primer peronismo y la enseñanza jurídica universitaria. Protagonistas, actitudes y reocupaciones". Cuadernos del Instituto Antonio de Nebrija de Estudios sobre la Universidad, №1, Vol. 11. Madrid, 2008, pp. 13-23.

Fernando Devoto y Nora Pagano. Historia de la historiografía argentina. Buenos Aires, Sudamericana, 2009.

Gabriel Del Mazo. El federalismo argentino y la reforma de la Constitución. Buenos Aires, Nemesio A. Ferrari, 1949. 


\section{La reforma constitucional de 1949: influencias y apoyos intelectuales a la iniciativa peronista}

George Mosse. La cultura europea del siglo XIX. Madrid, Ariel, pp. 12-13.

Joaquín Díaz de Vivar. "La Carta de Filadelfia y la Constitución Argentina”, Hechos e Ideas, № 53, Año IX. Buenos Aires, 1948, pp. 159-167.

John William Cooke. "La Constitución debe ajustarse a la realidad del país", Hechos e Ideas, № 53, Año IX. Buenos Aires, 1948, pp. 168-177.

Jorge Reinaldo Vanossi. La Constitución nacional de 1949. Comunicación del académico Dr. Jorge Reinaldo Vanossi en sesión privada de la Academia Nacional de Ciencias Morales y Políticas, el 9 de noviembre de 2005. Buenos Aires, 2005, URL: https://www.ancmyp.org.ar/user/FILES/La_constitucion.pdf

José Carlos Chiaramonte. "Alberdi y el sentido de su federalismo". PolHIs, № 17, Año 9, 2016, pp. 9-21.

José Carlos Chiaramonte. Raíces históricas del federalismo latinoamericano. Buenos Aires, Sudamericana, 2016.

José Carlos Chiaramonte. Usos políticos de la historia: Lenguaje de clases y revisionismo histórico. Buenos Aires, Sudamericana, 2013.

José Enrique Rodó. Ariel. Buenos Aires, Cervantes, 1920, pp. 98 y 103-105.

Juan Atilio Bramuglia. "Hay que abandonar el sistema individualista en las reformas constitucionales". Hechos e Ideas, № 53, Año IX. Buenos Aires, 1948, p. 211-219.

Juan Domingo Perón. "La reforma constitucional asegurará y reforzará nuestro sistema de gobierno”. Hechos e Ideas, № 53, Año IX. Buenos Aires, 1948, pp. 143148.

Juan F. Castro. Reforma de la Constitución. Buenos Aires, 1948.

Juan Fernando Segovia. "El modelo corporativista de estado en la Argentina, 19301945: Entre el derecho, la política y la ideología". Revista de Historia del Derecho, № 34. Buenos Aires, 2006, pp. 269-335.

Julio Herrera. "La evolución social y económica impone la reforma constitucional". Hechos e Ideas, № 53, Año IX. Buenos Aires, 1948, p. 194-198.

Lorenzo Soler (h). "La Constitución del 53, ya cumplió su misión en nuestra vida institucional”, Hechos e Ideas, № 53, Año IX. Buenos Aires, 1948, pp. 230-233.

Luis Delepiane. "El petróleo de México y el deber argentino", en Ana Jaramillo, Cuadernos de FORJA. Remedios de Escalada, UNLA, 2012, pp.199-220.

Manuel Gálvez. "La obra social que desarrolla el coronel perón", en Coronel Juan Perón, El pueblo quiere saber de qué se trata. Buenos Aires, 1944, pp. 7-9. 


\section{Gonzalo Rubio García}

Manuel Gálvez. El diario de Gabriel Quiroga. Opiniones sobre la vida argentina. Buenos Aires, Taurus, 2001.

Manuel Gálvez. El Solar de la Raza. Madrid, Saturnino Calleja SA, MCMXX.

Miguel A. Rodríguez de la Torre. Ante el problema de la reforma constitucional. Buenos Aires, 1948.

Miguel A. Tanco. "Las constituciones son leyes humanas y, como tales, no son inmutables”. Hechos e Ideas, № 53, Año IX. Buenos Aires, 1948, p. 222-229.

Norberto Galasso. Vida de Scalabrini Ortiz. Buenos Aires, Colihue, 2008.

Oscar Terán. Historia de las ideas en la Argentina: Diez lecciones iniciales, 1810-1980. Buenos Aires, Siglo Veintiuno, 2012.

Pablo A. Ramella. "Toda Constitución es producto de un proceso histórico y revolucionario". Hechos e Ideas, № 53, Año IX. Buenos Aires, 1948, pp.178-184.

Peter Linebaugh y Marcus Rediker. 'Una 'cuadrilla variopinta' en la revolución americana", en La hidra de la Revolución. Marineros, esclavos y campesinos en la historia oculta del Atlántico. Barcelona, Crítica, 2005, pp. 203-285.

Raúl Scalabrini Ortiz. El capital, el hombre y la propiedad en la vieja y en la nueva Constitución. Buenos Aires, Reconquista, 1948.

Raúl Scalabrini Ortiz. El hombre que está solo y espera. Buenos Aires, Albatros, 1951.

Raúl Scalabrini Ortiz. Política británica en el Río de la Plata. Buenos Aires, Reconquista, 1940.

Reinhart Koselleck. Historias de conceptos. Estudios sobre semántica y pragmática del lenguaje político y social. Madrid, Trotta, 2012.

Santiago Régolo. Hacia una democracia de masas. Aproximaciones históricosociológicas a la reforma constitucional de 1949. Buenos Aires, Instituto Nacional de Investigaciones Históricas Eva Perón, 2013.

Tulio Halperín Donghi. Argentina en el Callejón. Buenos Aires, Ariel, 2006, p. 133.

Vicente Bagnasco. "El porqué de las reformas a la Constitución". Hechos e Ideas, № 53, Año IX. Buenos Aires, 1948, pp. 149-158.

Recibido: 30/10/2017

Evaluado: $28 / 12 / 2017$

Versión Final: 17/01/2018 